\title{
English Writing Errors of Non-English Department Students
}

\author{
Hengki Yudha Barnaba ${ }^{1 *}$, Andi Dian Rahmawan² \\ 1,2 University of PGRI Yogyakarta, Indonesia
}

\begin{tabular}{l|l|l|l|} 
Contact: & Hengki Yudha Barnaba & ad.rahmawan@gmail.com
\end{tabular}

\begin{abstract}
This research sheds a light on students' erroneous on writing English paragraphs. Special attention would be given to the way students generating proper vocabulary and lexeme and the word orders. The researchers believe that the erroneous are resulted from the mismatched learning styles and preference being implemented. For that, this research attempts to reveal the relationship between students' learning preferences during the process of English learning in senior high school and the error being produced while producing the academic texts or paragraphs. This is a survey research by employing 50 students as the research subjects from department of Elementary School Teacher Training and Mathematic Education of University of PGRI Yogyakarta. They are, both female and male, from various background and amount of exposure to English. Students were asked to produce four paragraphs, narrating the process of English learning during the high school. The errors are classified into errors in diction and error in word orders. The researchers make relation between the error and the learning styles being implemented during the school process. The results would be descriptively explained. Based on the research results, it is revealed that Kinesthetic was the mostused method by the students who have the highest level of English comprehension. The reason is that the students are scaffolding, doing something to support the learning process. So, the learning goals are easily comprehended. It is strongly suggested that the teachers do carefully consideration to find the best approaches to teach materials by recognizing all students learning preferences in a classroom.
\end{abstract}

\section{KEYWORDS:}

Learning styles;

Writing products;

Learning goals.

\section{Introduction}

Writing is the highest level order of thinking. Students in the university level are

expected to be able to write, academically, idea and thought as a way to develop civilization. However, writing academic English is not merely writing on a piece of paper. More than that, students should possess high capabilities on diction and sentence structures. (Rus, 2016).There is another thing that cannot be ignored, that is the logical thinking order. There are principles 
regarding how to put sentence by sentence and paragraph by paragraph, and they are not so easy to comprehend (Saadat $\&$ Dastgerdi, 2014).

Students may have various learning styles, different learning styles and different responses to learning environments and instructional practices (Azida \& Bilal, 2013). Learning style has a positive relation to what the best circumstances that the students are in their best way and time to learn the materials. It is what we call as English Learning Preferences. The learning preferences depend fully on the learning experiences, as Kolb (1984) stated that learning is based on experience. Sometimes, a good experience on learning English will give positive impact on the successfulness of achieving the learning goals. On the other hand, bad experiences will give the negative ones. This research focuses on the low ability of the students of the first year in the University of PGRI Yogyakarta on writing English by giving special attention on how English is learnt during their years in senior high school. This research is going to reveal the students' activities of English learning processes in senior high school which impacts on the level of English comprehension when they are in the university level. It is expected that the readers of this research are benefited from the results of this research that the problems of the low quality of students' writing would be revealed.

The researcher has an expectation that the English teacher has capability to identify all learning styles of his students in a classroom so that the teacher may design the lesson plan to match the students' learning preferences. It is hard to imagine that a particular method being implemented in a particular classroom in a particular circumstance will accommodate all students' learning preferences. However, by recognizing all students' learning styles, a teacher's teaching method is going to approach all students' preferences such as visual and kinesthetic. In a classroom, there are students who have willing to participate actively, answer all teachers' questions, give feedback and improve the communication capabilities both oral and written. On the other hand, there are students who are hesitance to take participation during the classroom 
processes. They are more focus on sentence structures, for example, and have no interest on speaking. The worse, there are also students who have no interest at all on English. They have perspectives that others subjects, such as Mathematics and Physics, are more expected to gain the brighter future.

It is better for every teacher to put himself and the students in a proper circumstance, meaning that teacher should accommodate all students' learning styles. Found. There are various learning styles that do exist, namely Active and Reflective learners, Sensing and Intuitive Learners, Visual and Verbal learners and the Sequential and Global learners (Eva, 2016). By understanding the students' learning styles, the teacher can meet the students' need to find the learning goals effectively and efficiently (Aisami, 2015). According to his research, students learn best when the teacher applies visual learning, although it is not entirely new. At first, teacher may use colorful chalks on the blackboard, colorful markers on the whiteboard to attract children's interest on materials. Later, slides and transparency are also employed. Another research conducted by (Soodmand, Sohrabi, \& Malek, 2015) stated that there are 3 elements that have relationship, those are learning styles, learning strategies and English language achievement. It says that learning styles do not give impact to the learning achievement; it affects the students' way to manage the learning strategies. However, learning strategies do has big impact to the learning achievement. However, it is still arguable that a student has stagnant learning style (Hajar, Naimie, \& Sira, 2015). Their research reveals that students' learning styles are flexible and can be changed depending on their experience in the classroom because each student is an individual with a different objective, learning style, capability and ambition. By identifying each student's learning style, teacher is expected to make the personalized learning does happen based on student's preferred learning circumstances (Azida \& Bilal, 2013). This research offers teachers to use web, graphic, metadata, text and video. However, based on this research, students learn best when they are exposed to the video one. Visual learning method has been found as the most 
suitable one (Omar, Mohamad, \& Nazura, 2015). They applied this method to the students of electrical engineering and found that the subjects tend to be socially learning, comfortable working in groups and prefer to provide information for their friends, and be able to remember things easily. From this, we can reveal another fact that single learning style is not preferred. some students learn better with concrete, experiential type of educational experiences while others prefer reflective types of learning opportunities, such as discussion (social learners) or case study (Maric, Penger, Todorovic, Djurica, \& Pintar, 2015).

The ability to write English properly is equally important the same with the ability to speak English fluent. The post-communicative turn in English methodology has reconsidered the importance of writing skill for language acquisition, after a period in which writing was neglected during English classes to the detriment of speaking (Rus, 2016). Scientists are still arguing which method is applicable to train students to write English well. Can 'free writing' be used as one of the way? It is suggested teacher to propose students to write diary writing as an alternative way to stimulate students to produce a piece of writing (Klimova, 2015). The purpose of this is the teacher can learn from students' diaries about their constraints in writing and help them to remove them. The obstacle is that not all the students are willing to share it with their teacher and not all the students are ready to write the diary entries as the course has shown so far, since diaries are something which are very personal. This is supported by another research revealing that the application of creative writing activities is effective in increasing 7th grade students' writing achievement in English (Tok, 2015). Those methods are deserved to be tested as a way to eliminate the foreign language anxiety learning since it has significance negative effects it can have on language learning, performance, achievement and perception towards the whole educational process (Hasan $\&$ Qashoa, 2014). The research proposes the strategies such as self-confidence, enhancing background knowledge, creating positive attitudes toward 
committing mistakes, peer correction and relaxation exercises. From teachers' perspectives, affective alleviating strategies are reported such as building up self-confidence among students, encouraging students to accept positive criticism and view mistakes as an important part of the learning process. To learn and practice English writing, teacher can utilize technology such as computer multimedia. For this, human activities are gradually promoted by the development of society, while the development of society and technology can greatly put forward educational development. In such kind of information society, we should adapt actively, make full use of developing information technology to train students' creating and practicing ability. This is the way to improve teaching quality (Guan, Song, Guan, Song, \& Li, 2018). Another teaching writing method proposed is by using e-portfolio (Fukunaga, 2018). It says that e-portfolios have great potential because they help the research subjects to gain knowledge of the foundational concepts of writing and become skillful in writing for a wide variety of audiences and in a wide variety of genres with specific purposes in mind.

\section{Method}

There are 50 subjects of this research; consisting 18-21 year old male and female from various ethnic background and level of English exposure. They are the students of elementary teacher training program Mathematic Education at the University of PGRI Yogyakarta. To gain the research data, all of the subjects are required to make four paragraphs of academic writing regarding the English teaching method been exposed during their senior high school to reveal the most used learning style applied by their English teachers. After the data gained, the researcher categorized them into four categorizations, namely visual, auditory, kinesthetic and reflective. The correlations between the learning styles and the kinds of error regarding diction and word order are intended to reveal to find the most appropriate teaching method as a way to minimize error production. 


\section{Result}

The 50 data were collected and divided into four categories, namely visual, kinesthetic, and auditory and the reflective learning styles. The researcher did the carefully observation to decide where each datum belongs to. The following tables are the description of each data violation to the error of diction and grammatical aspects. It is intended to know which learning and teaching style generates more error than others.

Table 1 Errors of Visual Learners

\begin{tabular}{|c|c|c|}
\hline \multirow{2}{*}{$\begin{array}{c}\text { Data } \\
\text { Number }\end{array}$} & \multicolumn{2}{|c|}{ Kinds of Errors } \\
\hline & Diction & Grammatical Aspects \\
\hline 1 & $\begin{array}{l}\text { Alamat = address my residence } \\
\text { Ribut }=\text { crowded } \\
\text { Tidak membosankan = not very boring }\end{array}$ & English lesson were \\
\hline 2 & $\begin{array}{l}\text { Bahasa Inggris = English language } \\
\text { Ketika saya kelas } 11 \text { dan } 12=\text { when I class } \\
11 \text { and } 12 \\
\text { Menerima materi = receive material }\end{array}$ & $\begin{array}{l}\text { Will description } \\
\text { There is } 2 \text { teacher } \\
\text { When he very relaxed } \\
\text { But he very smart } \\
\text { He very discipline } \\
\text { Some example }\end{array}$ \\
\hline 3 & $\begin{array}{l}\text { Pelajaran menulis= wrote } \\
\text { Tidak suka pelajaran Bahasa Inggris = less } \\
\text { like a lesson English } \\
\text { Banyak member tugas = many giving the } \\
\text { task } \\
\text { Ketika belajar di kelas } 10=\text { on learning the } \\
\text { tenth grade } \\
\text { Karena saya tidak terlalu lancar = because } \\
\text { have not so smoothly } \\
\text { Kelas } 12=\text { grade twelve English }\end{array}$ & English is one of...have \\
\hline
\end{tabular}

The table above explains us how visual learners come to erroneous on diction and grammatical aspects.

\section{Discussion}

According to the data, students tend to use diction purely 'word for word'. They are also lack of capability on using cardinal and ordinal numbers based on context, it also effects on how students translate the sentences. Students also have difficulty on using proper auxiliaries in sentences, sometimes it is missing and sometimes it is misused. Visual learners tends to use notes to memorize learning material, considering the errors, it can be categorized as the not- 
effective learners (Wong \& Nunan, 2011). It has been stated that visual learners prefer to study alone in a quiet place to read books and articles, they avoid discussion with friends. They are better at listening to the teacher's presentation and make notes on it. The notes would be simply written to make it easy to memorize.

Table 2. Errors of Auditory Learners

\begin{tabular}{|c|c|c|}
\hline \multirow{2}{*}{$\begin{array}{c}\text { Data } \\
\text { Number }\end{array}$} & \multicolumn{2}{|c|}{ Kinds of Error } \\
\hline & Dictions & Grammatical Aspects \\
\hline 1 & $\begin{array}{l}\text { Jarang masuk = very rarely in class } \\
\text { Baru melahirkan = has just finished giving } \\
\text { birth } \\
\text { Menerima materi Bahasa Inggris = } \\
\text { received English language learning }\end{array}$ & To wrote \\
\hline 2 & $\begin{array}{l}\text { Memberikan pertanyaan = gives me a } \\
\text { question to do } \\
\text { Ketika saya kelas } 3=\text { when I entered the } \\
\text { third grade. }\end{array}$ & $\begin{array}{l}\text { My was born } \\
\text { A English teacher }\end{array}$ \\
\hline 3 & $\begin{array}{l}\text { Saya diajar dari kelas } 10-12=\underline{\text { lam in }} \\
\text { teaching from class } 10 \text { to } 12 \\
\text { Pelajarannya sangat sedikit ketika kelas } 11 \\
=\text { when the grade } 11 \text { subjects is very less. } \\
\text { Ketika saya naik kelas } 12=\underline{\text { when l entered }} \\
\text { grade } 12 .\end{array}$ & No Errors \\
\hline 4 & $\begin{array}{l}\text { Penjelasannya susah dipahami }=\underline{I t ' s} \\
\text { delivery difficult to be clearly accepted. } \\
\text { Sekolah }=\underline{\text { scholl }}\end{array}$ & No Errors \\
\hline 5 & $\begin{array}{l}\text { Untuk menulis surat sebaik mungkin = to } \\
\text { makea letter as good as } \\
\text { Tampil = appear } \\
\text { Menambah pengalaman = add more } \\
\text { experience. }\end{array}$ & No Errors \\
\hline
\end{tabular}




\begin{tabular}{|c|c|c|}
\hline 6 & $\begin{array}{l}\text { Saya masuk sekolah = I entered school } \\
\text { Semester } 1 \text { = semester } 1 \\
\text { Ketika kelas saya rebut = when the sound } \\
\text { of my class was always crowded } \\
\text { Materinya dimasukkan dikelas XI = the } \\
\text { material is entered in class XI } \\
\text { Tidak semuanya dapat ditangkap dan } \\
\text { diingat = not everything can be captured in } \\
\text { a good memory } \\
\text { Kelasku sering kosong = my class is often } \\
\text { empty } \\
\text { Ketika sedang masuk kelas = when } \\
\text { entering theclass } \\
\text { Menyimpan dalam ingatan = deposits } \\
\text { memorization } \\
\text { Mengumpulkan tugas = collecting } \\
\text { assignments } \\
\text { Menangkap materi = catch material }\end{array}$ & No Errors \\
\hline 7 & $\begin{array}{l}\text { Ketika saya duduk di bangku SMA = When } \\
\text { I sat in my high school } \\
\text { Bahasa Inggrisku kaku = my English is stiff. } \\
\text { Ketika saya masih SMA kelas I = When I } \\
\text { was in high school class I }\end{array}$ & No Errors \\
\hline 8 & No Errors & No Errors \\
\hline 9 & $\begin{array}{l}\text { Alamat rumah = Address of my house } \\
\text { Saya masuk ke jurusan IPA = I entered the } \\
\text { science study program } \\
\text { J ika ada keributan = If there is a crowd } \\
\text { Selama kelas } 3=\text { during class } 3\end{array}$ & No Errors \\
\hline 10 & Membuat kalimat = compose sentences & No Errors \\
\hline 11 & $\begin{array}{l}\text { Siswa baru = new student } \\
\text { Mengumpulkan tugas = collect the } \\
\text { assignment }\end{array}$ & No Errors \\
\hline 12 & $\begin{array}{l}\text { Menulis di dalam buku = write it behind } \\
\text { the book } \\
\text { Nilai/skor = value } \\
\text { Di kelas } 1=\text { in class } 1 \\
\text { Waktu berlalu dengan cepat = timeto run } \\
\text { quickly }\end{array}$ & No Errors \\
\hline 13 & Kelas $10=$ class 10 & No Errors \\
\hline 14 & No Errors & No Errors \\
\hline 15 & $\begin{array}{l}\text { Tapi sayangnya = but my dear } \\
\text { Guru mengajar sampai saya bisa = teacher } \\
\text { teaches until I can } \\
\text { Motivasi sendiri = motivation of each }\end{array}$ & No Errors \\
\hline 16 & $\begin{array}{l}\text { Saya masuk SMA = I entered high school } \\
\text { Naik kelas } 2=\text { entering the second grade } \\
\text { Sedikit demi sedikit = little by little }\end{array}$ & \\
\hline 17 & $\begin{array}{l}\text { Sangat tidak menarik = was not very } \\
\text { interested }\end{array}$ & No Errors \\
\hline 18 & - & No Errors \\
\hline 19 & $\begin{array}{l}\text { Ketika kelas } 1=\text { when grade } 1 \\
\text { Diluar jam belajar Bahasa Ing gris = outside } \\
\text { of the hours of English learning }\end{array}$ & No Errors \\
\hline 20 & Tidak masuk kelas = did not enter the & No Errors \\
\hline
\end{tabular}




\begin{tabular}{lll}
\hline & class \\
\hline 21 & $\begin{array}{l}\text { Otakku tidak dapat mencerna = my brain } \\
\text { is not capable of digesting } \\
\text { Apa daya = what power }\end{array}$ \\
\hline
\end{tabular}

The auditory learners learn best when they are involved in a discussion, both teachers and classmates and enjoy most at listening at tape, video and interview (Ed \& Ph, 2017). This is in accordance with the data displayed in the box above; students have no difficulties on sentence structure, because they are used to have conversation and discussion to train their abilities to communicate spontaneously, the structure of the sentences would be properly arranged to assure that the message would be well transferred.

Table 3. Errors of Kinesthetic Learners

\begin{tabular}{|c|c|c|}
\hline \multirow{2}{*}{$\begin{array}{l}\text { Data } \\
\text { Number }\end{array}$} & \multicolumn{2}{|c|}{ Kinds of Error } \\
\hline & Dictions & Grammatical Aspects \\
\hline 1 & Menyarankan = submit suggestions & No Errors \\
\hline 2 & $\begin{array}{l}\text { Kesimpulan yang dapat saya ambil = } \\
\text { conclusion that I can take }\end{array}$ & No Errors \\
\hline 3 & $\begin{array}{l}\text { Mahasiswa = student college } \\
\text { Kelas IPA = class science } \\
\text { Saya masuk kelas Bahasa Ingggris = I } \\
\text { entered English class } \\
\text { Saya bertemu lagi = I again met } \\
\text { Nilai/skor = values }\end{array}$ & No Errors \\
\hline 4 & $\begin{array}{l}\text { Kita diajarkan untuk membaca = weare } \\
\text { taught to read } \\
\text { Saya kaku dalam menggunakan Bahasa } \\
\text { Inggris = I am stiff in using English } \\
\text { Terkadang masuk kelas = sometimes } \\
\text { entering the class } \\
\text { Sedikit demi sedikit = little by little } \\
\text { Semester } 1 \text { dan } 2 \text { = semester one and two }\end{array}$ & No Errors \\
\hline 5 & $\begin{array}{l}\text { Saya lulusan } 2016=\text { I am a class of } 2016 \\
\text { Kelompok = clusters }\end{array}$ & No Errors \\
\hline 6 & $\begin{array}{l}\text { Alamat rumah = address my residence } \\
\text { Berisik = crowded }\end{array}$ & No Errors \\
\hline 7 & Skor = value & No Errors \\
\hline & Menjadi sedikit = becomes a little & \\
\hline 8 & No Errors & No Errors \\
\hline 9 & $\begin{array}{l}\text { Ketika saya kelas } 10=\text { Time I the tenth grade } \\
\text { Naik kelas } 11=\text { l upgrade eleven }\end{array}$ & No Errors \\
\hline 10 & Pengajarannya = his services & No Errors \\
\hline 11 & $\begin{array}{l}\text { Sedikit demi sedikit = little by little } \\
\text { Mematuhinya = followed him }\end{array}$ & No Errors \\
\hline
\end{tabular}




\begin{tabular}{cll}
\hline 12 & $\begin{array}{l}\text { Ketika saya duduk di bangku MA = When I } \\
\text { sat in MA }\end{array}$ & No Errors \\
\hline 13 & $\begin{array}{l}\text { Mengumpulkan tugas = gather the } \\
\text { assignment }\end{array}$ & No Errors \\
\hline 14 & $\begin{array}{l}\text { Sekolah favorit = school favorite } \\
\text { Kelas 11 = class eleven }\end{array}$ & No Errors \\
\hline 15 & $\begin{array}{l}\text { Ketika saya masuk kuliah = when I entered } \\
\text { the college }\end{array}$ & No Errors \\
\hline 16 & $\begin{array}{l}\text { Saya jurusan marketing = lentered the } \\
\text { marketing department }\end{array}$ & No Errors \\
\hline
\end{tabular}

Kinesthetic learners have less difficulty on sentence structure, compared to other styles. This is not wondering since Kinesthetic is more 'practical', do what they have learnt so that the students are more into with the learning material (Martinez \& Tuesca, 2017).

Table 4. Errors of Reflective Learners

\begin{tabular}{lll}
\hline \multirow{2}{*}{$\begin{array}{c}\text { Data } \\
\text { Number }\end{array}$} & \multicolumn{1}{c}{ Kinds of Error } \\
\cline { 2 - 3 } & \multicolumn{1}{c}{ Diction } & \multicolumn{1}{c}{ Grammatical Aspects } \\
\hline 1 & No Error & No Error \\
\hline 2 & No Error & No Error \\
\hline 3 & No Error & No Error \\
\hline 4 & Kepribadiannya = his person & No Error \\
\hline 5 & No Error & No Error \\
\hline 6 & Masuk SMA = high school entry & No Error \\
\hline 7 & No Error & No Error \\
\hline 8 & No Error & No Error \\
\hline 9 & Kelas 3 =Class 3 & A notes \\
\hline 10 & No Error & No Error \\
\hline
\end{tabular}

It is revealed that the reflective learners are the least error producers among others and the error productive is the kinesthetic learners. Reflective has the meaning that the students are given the time to contemplate the learning material that has been exposed, before the students are ready for the next ones. It is not wondering since the students have time to do the trial and error and also exercises to strengthen the understandings. Most of us believe that Kinesthetic is the best circumstance for students, since they have chance 'to do' the learning material. In fact, reflection is the fundamental need that should be given to our students. 


\section{Conclusion}

This research proposes teachers to give chance to students to re-thinking and re-exercising related to the learning material that has been taught. No matter what the preferred learning styles that attached to every student, still, they need extra time to contemplate and do trial and error to maximize the understanding on the material. There is tendency that the erroneous looks a like among those three learning styles; visual, auditory and kinesthetic. This research proposed that there is less relationship between learning style or learning preference with the learning achievement, but more with the learning strategy (Soodmand et al., 2015).

\section{Acknowledgement}

The highest gratitude would be addressed to University of PGRI Yogyakarta for the funds and permission so that this research can be accomplished without any obstacles.

\section{References}

Aisami, R. S. (2015). Learning styles and visual literacy for learning and performance. Procedia - Social and Behavioral Sciences, 176, 538-545. https://doi.org/10.1016/j.sbspro.2015.01.508

Azida, N., \& Bilal, M. (2013). Personalized learning and learning style among upper secondary school students. Procedia - Social and Behavioral Sciences, 103(2007), 710-716. https://doi.org/10.1016/j.sbspro.2013.10.391

Ed, J. C. M., \& Ph, C. O. D. (2017). Determination of Auditory And Visual Learning Styles of Adult Learners in Adult Literacy Centres in Anambra State , Nigeria ., 7(3), 30-33. https://doi.org/10.9790/7388-0703053033

Eva, Š. (2016). Detection of Learning Styles in the Focus Group, 217, 177-182. https://doi.org/10.1016/j.sbspro.2016.02.057

Fukunaga, S. (2018). English writing eportfolio for university STEM majors English writing eportfolio for university STEM majors, 00. https://doi.org/10.1016/j.procs.2018.08.130

Guan, N., Song, J., Guan, N., Song, J., \& Li, D. (2018). On the Advantages of Computer Multimedia-aided English Teaching On the Advantages English. https://doi.org/10.1016/j.procs.2018.04.317

Hajar, S., Naimie, Z., \& Sira, S. (2015). Exploring The Link Between Learning Styles And Gender Among Distance Learners. Procedia - Social and Behavioral Sciences, 191, 1082-1086. https://doi.org/10.1016/j.sbspro.2015.04.238 
Hasan, S., \& Qashoa, H. (2014). English writing anxiety : alleviating strategies. Procedia - Social and Behavioral Sciences, 136, 59-65. https://doi.org/10.1016/j.sbspro.2014.05.288

Klimova, B. (2015). Diary writing as a tool for students 'self-reflection and teacher' $s$ feedback in the Course of Academic Writing. Procedia - Social and Behavioral Sciences, 197(February), 549-553. https://doi.org/10.1016/j.sbspro.2015.07.189

Maric, M., Penger, S., Todorovic, I., Djurica, N., \& Pintar, R. (2015). Differences in Learning Styles : A comparison of Slovenian Universities. Procedia - Social and Behavioral Sciences, 197(February), 175-183. https://doi.org/10.1016/j.sbspro.2015.07.079

Martinez, E. G., \& Tuesca, R. (2017). learning styles and gross autonomy assessment outcomes at a Colombian School of Medicine, (xx).

Omar, N., Mohamad, M. M., \& Nazura, A. (2015). Dimension of Learning Styles and Students 'Academic Achievement. Procedia - Social and Behavioral Sciences, 204(November 2014), 172-182. https://doi.org/10.1016/j.sbspro.2015.08.130

Rus, D. (2016). A Didactic Approach to Writing Skills in a Technical Learning Environment, 22(October 2015), 1191-1196. https://doi.org/10.1016/j.protcy.2016.01.167

Saadat, M., \& Dastgerdi, M. F. (2014). Correlates of L2 Writing Ability of Iranian Students Majoring in English. Procedia - Social and Behavioral Sciences, 98, 1572-1579. https://doi.org/10.1016/j.sbspro.2014.03.580

Soodmand, H., Sohrabi, S., \& Malek, R. (2015). On the Relationship among Iranian ESP L earners ' Learning Strategy Use, Learning Styles and their English LanguageAchievement. Procedia - Social and Behavioral Sciences, 192, 724-729. https://doi.org/10.1016/j.sbspro.2015.06.079

Tok, Ş. (2015). Effects of creative writing activities on students ' achievement in writing, writing dispositions and attitude to English ., 174, 1635-1642. https://doi.org/10.1016/j.sbspro.2015.01.815

Wong, L. L. C., \& Nunan, D. (2011). The learning styles and strategies of effective language learners. System, 39(2), 144-163. https://doi.org/10.1016/j.system.2011.05.004 